\title{
Społeczna percepcja wyborów 2019 roku
}

\author{
Social Perception of Election in 2019
}

Stowa kluczowe: wybory, spostrzeganiespołeczne, indywidualnapercepcja rzeczywistości, emocje w polityce

Keywords: elections, social perception, individual perception of reality, emotions in politics

Abstrakt: Przedmiotem artykułu jest analiza społecznej percepcji wyborów parlamentarnych z 2019 roku. Analiza ta została dokonana na dwóch wymiarach percepcji polityki: indywidualnej oraz kolektywnej, zobrazowanej w badaniach społecznych przed wyborami i po nich. Celem naukowym artykułu jest próba zbudowania struktury procesu spostrzegania wyborów. Odniesieniem teoretycznym stały się koncepcje kształtowania obrazów zjawisk i wydarzeń politycznych.

* ORCID ID: https://orcid.org/0000-0001-7686-8509, doktor habilitowana nauk społecznych w zakresie nauk o polityce, Wydział Nauk Politycznych i Studiów Międzynarodowych, Uniwersytet Warszawski. W latach 2016-2019 dyrektor Instytutu Nauk Politycznych UW, w latach 2005-2015 pełniła funkcję wicedyrektora INP. Zajmuje się mechanizmami komunikowania politycznego, psychologicznymi aspektami komunikacji społecznej i zachowaniami politycznymi (uwarunkowania aktywności politycznej i społecznej), kształtowaniem wizerunku i autoprezentacjami, stylami komunikowania się, strategiami marketingowymi i PR). Autorka publikacji naukowych na temat komunikacji politycznej, personalizacji polityki i zachowań wyborczych. Trener komunikacji interpersonalnej. Ekspert Polskiej Komisji Akredytacyjnej w dyscyplinie nauki o polityce, członkini Polskiego Towarzystwa Komunikacji Społecznej oraz Komitetu Nauk Politycznych Polskiej Akademii Nauk. Email: e.marciniak@uw.edu.pl. 
Abstract: The subject of the article is an analysis of the social perception of the 2019 parliamentary elections. This analysis was performed on two dimensions: individual perception of politics and collective, illustrated in social research before and after the elections. The scientific goal of the article is an attempt to build the structure of the process of perceiving elections. The theoretical reference are the concepts of shaping images of political phenomena and events.

\section{Wprowadzenie}

Rzeczywistość społeczno-polityczna jest skomplikowanym obiektem percepcji i ocen. Owa komplikacja skutkuje tym, że percepcja jest selektywna i fragmentaryczna. Ludzie dostrzegają tylko niektóre elementy tej rzeczywistości, na przykład takie, które są wyraziste i uznane za ważne1. Na społeczną percepcję wydarzeń politycznych ma wpływ z jednej strony subiektywna, z drugiej zaś podzielana społecznie ocena ich doniosłości. Subiektywna wiąże się z indywidualnymi przekonaniami na określony temat, a podzielana społecznie odnosi się do dominującej w danym okresie opinii publicznej. Indywidualny i społeczny ogląd zjawisk i wydarzeń politycznych stanowi istotny czynnik kształtowania się stosunku do polityki ergo do aktywności bądź jej zaniechania. Krystyna Skarżyńska akcentuje znaczenie indywidulanych przekonań i ocen zjawisk politycznych, przyjmuje, że „rzeczywistość społeczno-polityczna jest przeżywana i oceniana subiektywnie. Nie można zakładać, że wspólnota doświadczeń historycznych prowadzi do podobieństwa przeżyć i ocen danego okresu"2. Dalej autorka ta cytuje przemyślenia Jerzego Jedlickiego, który napisał, że „doświadczenie historyczne rozpada się na tysiące doświadczeń jednostkowych, prywatnych, które każdy, sam sobie, musi uporządkować, przetrawić i nazwać"3.

Trawestując tę myśl, można powiedzieć, że doświadczanie bieżących sytuacji politycznych czy wydarzeń również jest indywidulanie porządkowane, opisywane i zapamiętywane. Indywidualny stosunek do polityki ma jednak związek z dominującymi poglądami na dany temat. Konformizacja przekonań to dość powszechne zjawisko. Dlatego analizując to, jak kształtują się czy to obraz polityki w umysłach jednostek, czy jej

1 K. Skarżyńska, Potoczna percepcja i ewaluacja rzeczywistości społeczno-politycznej, [w:] J. Reykowski (red.), Potoczne wyobrażenia o demokracji. Psychologiczne uwarunkowania $i$ konsekwencje, Warszawa 1995, s. 69.

${ }^{2}$ Tamże, s. 67.

${ }^{3}$ J. Jedlicki, Walka dobra ze złem, «Polityka»1993, nr 48. 
percepcja, nie można abstrahować od opinii wyrażanej przez szerokie kręgi obywateli.

A to ma wiele istotnych konsekwencji. Sprzyja na przykład kształtowaniu poziomu i jakości kultury politycznej, na którą składają się przekonania i postawy wobec aktorów politycznych, ich decyzji, a także kluczowych politycznych wydarzeń. Nie ulega wątpliwości, że wybory parlamentarne należą do takich wydarzeń, które mogą utrwalać lub zmieniać kształt sceny politycznej, a zatem politykę w ogóle.

Rok 2019 był rokiem podwójnych wyborów w Polsce - do Parlamentu Europejskiego i parlamentu krajowego. Obie te elekcje odbywały się w atmosferze gorących dyskusji politycznych, których esencją była defacto ocena rządów Prawa i Sprawiedliwości. W rezultacie wybory ogniskowały uwagę społeczeństwa i poszczególnych jednostek w stopniu wyjątkowym. Ich rezultat bowiem był równoznaczny z aprobatą vs dezaprobatą rządzących.

Celem artykułu jest identyfikacja społecznej percepcji wyborów parlamentarnych w 2019 roku oraz zróżnicowanych elementów ją konstruujących. Rezultatem poznawczym tego artykułu będzie zatem skonstruowanie wieloelementowej struktury społecznej percepcji wyborów na poziomie indywidualnym i społecznym. Wywód będzie prowadzony wokół następujących problemów badawczych:

1. Jakie są konstytutywne elementy percepcji społecznej?

2. Jak kształtowała się percepcja wyborów wśród badanych osób?

3. Jakie było odzwierciedlenie wyborów w ogólnopolskich badaniach społecznych?

4. Jakie elementy kształtują strukturę społecznej percepcji wyborów parlamentarnych?

Rozwiązanie wskazanych problemów badawczych będzie możliwe poprzez zastosowanie krytycznej analizy piśmiennictwa oraz analizy i strukturyzacji kilkunastu wywiadów pogłębionych (IDI) oraz wyników badań społecznych przeprowadzonych przez CBOS.

\section{Pojęcie percepcji}

Na percepcję składają się różnorodne procesy poznawczo-emocjonalne. Na gruncie psychologii przyjmuje się, że jest to złożony proces odbierania i przetwarzania informacji o różnych obiektach, w tym o ludziach i sytuacjach społecznych. W wyniku spostrzegania powstają określone obrazy określonych podmiotów. Wielki słownik języka pol- 
skiego wymienia trzy bliskoznaczne słowa: percepcja, spostrzeganie i obserwacja. Czasami sens spostrzegania sprowadza się do widzenia aktywizacji zmysłu wzroku. Ale jest i szerszy sens - społeczny, zgodnie z którym spostrzeganie wiąże się dostrzeganiem zjawisk społecznych, nadawaniem im określonego znaczenia, interpretacją i zapamiętywaniem. Zatem, w przyjętym w tym tekście rozumieniu, spostrzeganie nie wiąże się z widzeniem w sensie zmysłowym, lecz z zauważaniem zjawisk politycznych zarówno przez indywidualne jednostki, jak i grupy społeczne.

Magdalena Ratalewska analizując ustalenia psychologów społecznych zauważa, że spostrzeganie społeczne jest rezultatem ukierunkowania uwagi, organizacją i interpretacją informacji z otaczającego świata4.

Kluczowym momentem jest tu uwaga. Gdyż tylko to, co jest zauważone, podlega kolejnym procesom swoistej poznawczo-emocjonalnej obróbki 5 . Świadomą uwagę zazwyczaj kierujemy na silne bodźce - takie, które czymś się wyróżniają, są inne, spektakularne.

M. Ratalewska pisze, że na to, co zostanie zauważone, mają wpływ nasze oczekiwania. Oczekiwania kierują uwagę na te informacje, które są z nimi zgodne ${ }^{6}$. Organizacja informacji to w gruncie rzeczy ich porządkowanie i kategoryzowanie. Dopasowanie nowych informacji do istniejących już w naszym umyśle zasobów wiedzy na dany temat jest sposobem na uczynienie pewnego ładu w informacjach. Dostrzeżone i uporządkowane informacje podlegają interpretacji, na podstawie których są formułowane wnioski oraz podejmowane decyzje. Gdy mowa o percepcji polityki, te wymienione etapy wydają się być obecne w powstawaniu sądów o polityce i kształtowaniu jej obrazu.

Skarżyńska nieco inaczej konceptualizuje proces spostrzegania. Wskazuje na trzy jego komponenty: atrybucję, przypisywanie oczekiwań i wywoływanie emocji7. Proces atrybucji zgodnie z ustaleniami Fritza Heidera ${ }^{8}$ polega na wnioskowaniu co do przyczyn określonych zachowań jednostek. Atrybucja wewnętrzna oznacza koncentrowanie się na cechach tych jednostek, na przykład ich osobowości, intelekcie, a atrybucja zewnętrzna polega na dostrzeganiu znaczenia czynników sytuacyjnych w ocenianiu przyczyn zachowań. Ludzie na ogół przeceniają znaczenie

${ }^{4}$ M. Ratalewska, Spostrzeganie społeczne ijego znaczenie w procesie komunikacji międzyludzkiej, «Studia Ekonomiczne Regionu Łódzkiego» 2013, nr 11, s. 160.

${ }^{5}$ Szerzej na temat uwagi w: E.M. Marciniak, Pozyskiwanie uwagi jako narzędzie marketingu politycznego, «Studia Politologiczne» 2010, vol. 16, s. 77.

${ }^{6}$ M. Ratalewska, Spostrzeganie społeczne..., s. 162.

${ }^{7}$ K. Skarżyńska, Spostrzeganie ludzi, Warszawa 1981, s. 7.

8 B. Wojciszke, Człowiek wśród ludzi. Zarys psychologii społecznej, Warszawa 2002, s. 99-101. 
cech w wyjaśnianiu przyczyn, przypisując im właśnie siłę sprawczą. Jest to tzw. podstawowy błąd atrybucji. Mechanizm ten jest obecny w polityce i określany jest jako personalizacja polityki ${ }^{9}$. Wyjaśnianie zjawisk politycznych poprzez odwoływanie się do indywidulanych cech polityków to stosunkowo powszechne zjawisko. Powszechne również ze względu na to, że ułatwia percepcję polityki.

Chodzi tu o to, iż jednostki mogą oceniać polityków stosując repertuar pojęć poznawczo dostępnych, powszechnie znanych, bo odnoszących się do cech ludzi, wydaje się im więc, że lepiej rozumieją politykę, potrafią ją opisywać, a nawet wyjaśniać. Zatem w procesie percepcji polityki odniesienie się do cech polityków odgrywa istotną rolę. Z drugiej zaś strony to politycy są bardziej skłonni do eksponowania swoich cech, w porównaniu

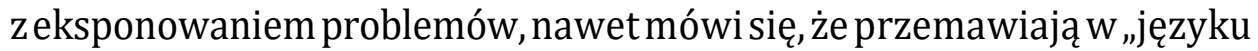
osobowości"10. Procesy atrybucyjne odpowiadają zatem za kształtowanie obrazów polityki i zjawisk w jej obrębie. Oczekiwania co do charakteru zdarzeń są kolejnym elementem percepcji społecznej ${ }^{11}$. Oczekiwania są konstruowane na podstawie wcześniejszych doświadczeń i zdarzeń. Mówią, jaki będzie nasz polityczny świat w przyszłości. Dokonując pozytywnej oceny pracy jakiegoś polityka aktualnej kadencji, oczekujemy, że w kolejnej będzie on również zasługiwał na pozytywną ocenę. Czyli oczekiwania ukierunkowują interpretację zarówno ludzi, jak i bieżących zdarzeń. Wpływają też na podejmowanie decyzji. Emocje jako kolejny element percepcji są istotnym filtrem w spostrzeganiu społecznym. Można więc popatrzeć na znaczenie emocji z perspektywy wyborców, którym przypisuje się emocjonalny stosunek do polityki. Z drugiej strony emocje są też obecne w przekazach polityków. Mowa wówczas o emocjonalnych wystąpieniach publicznych ${ }^{12}$.

Wywoływanie emocji w odniesieniu do zdarzeń politycznych, zwłaszcza w okresie kampanii wyborczej, to przedmiot zainteresowania naukowców. Helmut Schoeck jeszcze w latach sześćdziesiątych XX wieku pisał, że „Nawet gdyby walka wyborcza - co jest mało prawdopodobne - toczyła się jedynie na płaszczyźnie czysto intelektualnej z użyciem precyzyjnych logicznych argumentów, nie wydaje się, sądząc po małostkowej zazdrości

${ }_{9}^{9}$ E.M. Marciniak, Personalizacja zachowań wyborczych w Polscew kontekście Modelu Zgodności Preferencji Politycznych, Warszawa 2013, s. 25-30.

10 G.V.Caprara, Ph.G. Zimbardo, Personalizing Politics. A Congruency Model of Political Preference, «American Psychologist» 2004, vol. 59 (7).

11 D.T. Kenrick, S.L. Neuberg, R.B. Cialdini, Psychologia społeczna, przekł. A. Nowak i in., Gdańsk 2002, s. 96.

12 Ż. Krawczyk-Antońska, Pobudzić a zostać pobudzonym. Emocje w polityce, Katowice 2013, s. 8. 
i nierzadko irracjonalnych sprzeczkach i w gronie uczonych, i naukowców, aby poziom i ton demokratycznej debaty miały w konsekwencji ulec poprawie. Celem zawsze pozostanie unicestwienie punktu widzenia opozycji w imię własnej frakcji: bez względu na to, jak bardzo podatna będzie na racjonalny atak, bardziej opłacalna okaże się zawsze krytyka odwołująca się do podstawowych emocji"13. Wymieniona w tytule cytowanej książki emocja - zawiść - jest dobrze rozpoznana i praktykowana. Tkwi w niej bowiem silny potencjał polaryzacyjny. I nie tylko o taką negatywną emocję chodzi w polityce. Wywoływane są lęki, obawy, niepokoje, niechęć, a nawet wrogość. Ale są też obecne pozytywne emocje - nadzieja, zadowolenie z przewagi własnej opcji politycznej, radość ze zwycięstwa i wiele innych.

Reasumując naszkicowane rozważania na temat percepcji zjawisk społecznych, podkreślić należy, że wymienione podejścia są komplementarne i, ogólnie rzecz ujmując, akcentują znaczenie dostrzegania zdarzeń, ich oceny (racjonalnej vs emocjonalnej) i interpretacji.

Społeczną percepcję wyborów będę analizować, biorąc pod uwagę powyższe ustalenia, a zatem przedmiotem analiz będą wydarzenia, które ludzie zapamiętali, zinterpretowali, a także oczekiwania i wzbudzone emocje.

Analiza percepcji wyborów parlamentarnych i kampanii wyborczej w 2019 roku została przeprowadzona na podstawie komunikatów z badań CBOS oraz indywidulanych wywiadów, które przeprowadziłam w listopadzie 2019 roku w dobranej celowo grupie. Badania IDI miały charakter pilotażowy, a ich wyniki będą służyły w kolejnych etapach badań. Osobom badanym zadawałam otwarte pytania:

1. Co zwróciło Pani/Pana uwagę w kampanii wyborczej i wyborach?

2. Jakie oczekiwania ${ }^{14}$ i emocje wiązały się z wyborami i kampanią wyborczą?

3. Jakie znaczenie miały te wybory?

\section{Wyniki badań i ich analiza}

Zaprezentowane wyniki badań pilotażowych należy traktować jako wprowadzające do kolejnych faz procesu badawczego. Ograniczona liczba (15) osób badanych pozwala jedynie na zilustrowanie ich percepcji wyborów i może stanowić przesłankę do dalszych badań.

\footnotetext{
${ }^{13}$ H. Schoeck, Zawiść. Źródło agresji, destrukcji i biedy, przekł. K. Nowacki, Warszawa 2012, s. 227.

14 Miarą oczekiwań były prognozy poparcia wyborczego dla partii politycznych.
} 


\section{Indywidualna percepcja wyborów (analiza indywidualnych wywiadów)}

Przedstawiony w wywiadach obraz wyborów parlamentarnych jest stosunkowo zróżnicowany i wskazuje, że respondenci biorący udział w badaniu „po swojemu” interpretowali wydarzenia, uprzednio zwracając uwage na inne aspekty wyborów. W kilkunastu wywiadach w mniejszym stopniu zaznaczają się cechy „uwspólnionej” percepcji, w większym zaś ma ona indywidulany, subiektywny charakter. Nie oznacza to, że nie zarysowuje się pewna struktura percepcji wyborów. Przedstawię jedynie fragmenty wywiadów z wybranymi rozmówcami. Prezentacja wszystkich wywiadów, a nawet ich skrótowy opis, wykraczałby poza ramy artykułu.

\section{Na co zwracano uwagę?}

Dla części respondentów znaczące okazały się podziały na scenie politycznej i wynikająca z nich ostra kampania. To właśnie negatywny, polaryzujący przekaz koncentrował uwagę respondentów. Na przykład jedna z respondentek jest przekonana, że podział na PiS i antyPiS jest trwałym komponentem sceny politycznej i nic z tym nie da się zrobić (K5, l. 63, Warszawa ${ }^{15}$ ). Wyraźnie określa się ona po stronie partii rządzącej i na jej działaniach koncentrowała uwagę.

Czynnikiem, który przyciągał uwagę, była pośrednia znajomość kandydata. Jeden z respondentów (M1, l. 18, wieś na Mazowszu) w swojej wypowiedzi podkreślał silną identyfikację ze społecznością lokalną. W trakcie kampanii wyborczej jego uwagę zwrócił kandydat Prawa i Sprawiedliwości ze względu na fakt, iż jest spokrewniony z jego koleżanką z klasy. Rozmówca postrzega go jako człowieka uczynnego, dbającego o własną rodzinę, wrażliwego na lokalne potrzeby. Dostrzega też, że cechy kandydata wynikają z jego zawodu - jest strażakiem.

Na cechy kandydata zwracała uwagę respondentka K1 (1. 61, Warszawa, emerytka). W szczególności istotne dla niej było zachowanie Roberta Biedronia, który „wzbudził kontrowersje poprzez nieczytelne zachowania - nie fair". Oceniła je jako raczej parcie do władzy, a nie

15 Opis respondentów - rozmówców, których dotyczą przywołane opinie/wypowiedzi uzyskane w wywiadach, podawany jest według jednolitego schematu: Kx lub Mx (kobieta/mężczyzna i numer wywiadu), wiek, miejscowość zamieszkania; niekiedy też podawany jest status - np. emeryt. 
zrobienie czegoś dla ludzi: „raczej mnie wkurzył - podkreślała w wypowiedzi - pieniądze są dla niego ważniejsze niż misja".

Krytyczne oceny pojawiły się w kolejnych wypowiedziach. Respondentka K3 (l. 55, Warszawa) stwierdziła, że po ogłoszeniu wyników „zapamiętałam tryumfalizm PiS-u, a z kampanii wybitną brutalność i kłamstwa po obu stronach, chodzi mi o słownictwo używane w kampanii i dezawuowanie przeciwnika". Oczekiwała przed wyborami, że opozycja weźmie się w garść, „, postawi do pionu, ale niestety nic nie zrobili”. Dodawała dalej, że „PIS przerobił lekcję konwentu św. Katarzyny, dawno 20 lat temu, i powołał do życia wielką koalicję już drugi raz z rzędu”. Zapamiętała brak programów partii, ponieważ ogólniki, które pojawiały się we wszystkich wypowiedziach polityków, trudno nazwać programem. Trudno się zatem dziwić, że w tej kampanii wyborczej część wyborców zauważyła pojawienie się nowych ugrupowań.

Jeden z rozmówców (M3, l. 34, Warszawa) poszukiwał nowości w kampanii wyborczej i zwrócił uwagę na nowe koalicje ugrupowań politycznych: Lewicę Razem i Konfederację. Jego uwagę zwrócił Janusz Korwin-Mikke i prorynkowy program tej partii. Mimo iż negatywnie ocenia dotychczasową aktywność polityczną Korwin-Mikkego, to docenia fakt, że wokół tej osoby powstało nowe ugrupowanie, które w programie akcentuje potrzeby drobnych przedsiębiorców i minimalizację roli państwa w gospodarce. Można zatem wskazać na merytoryczną, programową przesłankę percepcji kampanii, choć postać lidera politycznego także odegrała sporą rolę. Podobnie ocenia kampanię respondentka K6 (l. 32, Warszawa), która twierdziła: „Konfederacja to było zaskoczenie. Cała reszta mnie nie zaskoczyła, tak jak poprzednie wybory. Liczyłam, że największa partia rządząca nie będzie miała większości. A, i jeszcze jedno zaskoczenie, że Lewica zdobyła tak dużo punktów. Byłam zadowolona, że jest nowa siła, żeby gonić tę władzę".

Wśród respondentów byli i tacy, którzy zwracali uwagę na jeden szczegół, jedno nazwisko. Na przykład respondent M4 (1. 65, podwarszawska wieś) wystawienie Michała Kamińskiego na listach do senatu uważał za śmiałe posunięcie.

\section{Jakie były oczekiwania i emocje?}

Rozmówcy formułowali zróżnicowane oczekiwania, co należy wiązać z ich doświadczeniem, etapem życia i ogólnym statusem społecznym. Na przykład młody człowiek (M1,1. 18, wieś na Mazowszu) podkreślał ocze- 
kiwania związane z załatwianiem uciążliwości w miejscu zamieszkania, wskazując na brak drogi dojazdowej i szybkiego Internetu. Rozmówca ten nie ma oczekiwań odnośnie do różnych kwestii krajowych. Zatem jego percepcja polityki ma silnie lokalny i personalny charakter.

Oczekiwanie, by na scenie politycznej pojawiła się trzecia siła, czyli SLD, pojawiło się w wypowiedzi respondentki K1 (l. 61, Warszawa), która wskazywała: „mam dość konfliktu, nie wierzę ani PiS-owi, ani PO”. Podkreślała w swojej wypowiedzi, że niespecjalnie sympatyzuje z SLD, ale jest zmęczona ciągłą wojną i pyskówką, co jej zdaniem zaprząta bardzo dużo czasu publicznego, każdy pretekst jest dobry do wzajemnych ataków. Oczekiwała, że politycy będą dyskutować w ważnych sprawach. Żadna ze stron nie jest w stanie ustąpić dla rzeczy ważnych dla nas, żeby doprowadzić do dialogu. „Obie [strony] się uparły i tylko konfrontacja wchodzi w grę, więc chodzi o władzę, a jest tyle spraw do załatwienia, chociaż jedną rzecz rozwiązać wiarygodnie, ale nie ma na to szans" konkludowała. Dodatkowo w jej wypowiedzi pojawiły się oczekiwania poważnej polityki. Interpretuje to jako załatwianie spraw związanych z jakością usług publicznych.

Wiele pozytywnych emocji i ocen kryło się w wypowiedzi respondentki K2 (1. 78, wieś na Mazowszu, emerytka). Niewiele zapamiętała z tej kampanii, ale potrafiła formułować oceny rządzących i czyniła to chętnie. Jest w tych ocenach odzwierciedlona ogromna aprobata dla polityki 500+, dzięki której „dzieci nie mdleją z głodu, jak za poprzedniej władzy, teraz nie ma ani jednego głodnego dziecka". Respondentka ta nie wyobraża sobie zmiany władzy, ponieważ każda zmiana wiązałaby się z utratą dobrobytu. Ocenia rządzących obecnie polityków in gremio jako uczciwych, dobrych gospodarzy, „dających innym żyć”. Jednocześnie nie potrafi wskazać, na kogo głosowała, pamięta jedynie, że był to kandydat Prawa i Sprawiedliwości. W podobnym w pewnym sensie tonie wypowiadał się respondent M2 (l. 40, podwarszawska miejscowość) - kampania wyborcza nie była dla niego interesująca,jego udziałw wyborach motywowany był koniecznością poparcia PO. Twierdzi, że zagłosował na kobietę, która miała takie nazwisko jak koleżanka z klasy. Dla niego priorytetowy był fakt, że była to lista Koalicji Obywatelskiej. Zatem, podobnie jak w przypadku tej pierwszej respondentki, kampania wyborcza umknęła jego uwadze - w podejmowaniu przez oboje decyzji wyborczych podstawową rolę odegrał zgeneralizowany stosunek do konkretnego ugrupowania/koalicji. W pierwszym przypadku zaufanie do rządzących, w drugim - niechęć do nich i aprobata dla KO, ale nie konkretnego polityka. W obu przypadkach brakuje wiedzy o kandydatach, do udziału w wyborach motywuje poparcie dla partii. 
Emocji nie kryła respondentka K3 (1. 55, Warszawa), gdy stwierdzała, że „idiotyczne rozdawnictwo niedługo nam się odbije czkawką - podczas gdy służba zdrowia zdycha i nie ma jej jak reanimować. Każde wybory są dla nas plebiscytem. Może gdyby byli w Polsce anarchiści, to bym się do nich zapisała".

To, czego się spodziewała po wyborach, wyraźnie określiła respondentka K5 (1. 63, Warszawa): „oczekiwania moje i mojej rodziny były takie, że PiS wygra i będzie kontynuacja. Myślałam tylko, że większym procentem zwyciężą, że dostaną powyżej 50\% - za tyle, co dobrego zrobili dla Polaków. Oczekiwałam też zmian w sądownictwie, że nie odpuszczą, jak wygrają". Dodawała ponadto, że wcześniej głosowała na tę partię,jest zadowolona z jej rządów i nareszcie może pozytywnie oceniać polityków

\section{Jakie dominowały interpretacje?}

W niektórych wypowiedziach brakowało interpretacji, w innych zaś okazywało się, że kampania wyborcza nie zaprzątała umysłu respondentów, ale za to mają względnie rozbudowane interpretacje. Jako przykład może służyć wypowiedź respondentki K4 (1.36, Warszawa). Kampania wyborcza była według niej starciem dwóch ugrupowań, nie było, jak to określiła, żadnych „dziwactw”, nowych polityków czy partii, którzy wykraczaliby poza przyjęte reguły gry politycznej. Przykładem takiego „dziwactwa” był dla niej Paweł Kukiz, gdy był kandydatem w wyborach prezydenckich, a następnie jego ugrupowanie Kukiz15. Wynik wyborów zinterpretowała jako logiczną konsekwencję rządów PiS i ich polityki społecznej. Aprobata wobec tego aspektu przeważa nad negacją innych aspektów polityki, na przykład polityki międzynarodowej czy ekologicznej. W interpretacji tej respondentki ludzie postrzegają rządy przez pryzmat oceny własnej sytuacji materialnej.

Ponadto w jej opinii Polacy to materialiści i pragmatycy, a nie idealiści, w związku z czym wynik wyborów jej nie zaskoczył. W podobnym tonie wypowiedział się respondent M4 (1.65, podwarszawska wieś): „Nic nie pamiętam z wyborów. Wyparłem to z pamięci. Miałem zerowe oczekiwania. Już się klasa polityczna tak skompromitowała w moich oczach, że nie powiem, gdzie ją mam. Może byłem ze dwa razy w życiu na wyborach. Mało mnie to obchodzi. Bo jakidziesz głosować, to godzisz się z tym. Może to głupie, może aspołeczne, ale tak robię". Negatywna ocena i interpretacja wyborów i polityków skutkuje, jak widać, zaniechaniem aktywności wyborczej - i to zaniechaniem świadomym. 
Pozytywneinterpretacje kampanii wyborczejwybrzmiały zustrespondentki K5 (1. 63, Warszawa). Według niej PiS bardzo starannie przygotował się do kampanii. „Jeździli po kraju, premier też, przekonywali wyborców. Mieli ściśle określony program: kontynuacja 500+, podwyżka emerytur, 13. i 14. emerytura, podwyższenie płacy minimalnej. A przeciwnicy nie mieli programu, nikt też nie chciał z wyborcami rozmawiać. Nikt nie chciał ich słuchać face to face. W PiS-ie były debaty cykliczne w dużych miastach z udziałem całej elity partii z Kaczyńskim na czele, pomimo że się źle czuł" - oceniła.

W interpretacjach pojawiały się przeciwstawne określenia i sądy - to, co dla jednych było zwycięstwem, dla innych stanowiło porażkę. Niektórzy respondenci ujawniali swoje poglądy, podkreślając rzeczową analizę programów wyborczych. Przykładem wypowiedź respondentki K6 (l. 50, Warszawa): „Przed wyborami zrobiliśmy z moim narzeczonym staranną analizę programów. Mam poczucie, że muszę zabrać głoś w tak ważnej sprawie. Sprawdziliśmy wszystkie programy. Przygotowana byłam na to, że PiS wygra, bo śledziłam informacje w mediach społecznościowych". Program tej partii interpretowała jako nadzieję na to, że „wreszcie nastąpi ład i porządek i prawo będzie przestrzegane. Nie działają na mnie populistyczne hasła, tylko to, co rząd robi dla przedsiębiorców".

\section{Społeczna percepcja wyborów w badaniach opinii społecznej}

W badaniach opinii publicznej diagnozowano przeważnie preferencje polityczne wyborców. Można przyjąć, że wiążą się one z określonymi oczekiwaniami co do rezultatów wyborów. Większość sondaży realizowanych przez ośrodki demoskopijne prognozowała zwycięstwo Prawa i Sprawiedliwości. CBOS tuż przed wyborami również diagnozował wynik korzystny dla partii rządzącej. W jednym z badań zapytano o to, czy było łatwo czy trudno podjąć decyzję, na kogo głosować. Łatwość w tym zakresie dostrzegło 91\% spośród wyborców PiS, w porównaniu do 74\% wyborców $\mathrm{KO}^{16}$. Z pewnością dużą rolę odegrały tu kształtujące się wcześniej preferencje wyborcze.

Po przeprowadzonych wyborach parlamentarnych CBOS zbadał, jakie były społeczne reakcje na ich wyniki. Okazuje się, że 47\% respondentów wyraziło zadowoleniezwyników wyborów doSejmu,a 50\%-zwynikówdo

16 Centrum Badania Opini Społecznej, Jak Polacy podejmowali decyzje w wyborach parlamentarnych, komunikat z badań nr 163/2019. 
Senatu. Jednocześnie niezadowolenie wyrażało odpowiednio 32\% i 24\%17. Jak dalej wskazują autorzy badania, aż 89\% wyborców Prawa i Sprawiedliwości jest zadowolonych z wyniku tych wyborów. Podkreślić trzeba, że był to wynik zgodny z oczekiwaniami - w tygodniu poprzedzającym wybory na zwycięstwo rządzącej formacji wskazywało aż 77\% respondentów. Zatem zwycięzca był w zasadzie oczywisty i łatwy do przewidzenia18.

Na społeczną percepcję wyborów składają się informacje o kandydatach. Badania CBOS w tym zakresie można interpretować dwojako. Bo oto wskazują one, że 51\% respondentów dowiedziało się mało o kandydatach w trakcie kampanii, a 29\% - że dużo ${ }^{19}$. Może to też oznaczać, że kandydaci byli - przynajmniej dla części respondentów - dobrze znani, więc kampania nie przyniosła im żadnych nowych informacji.

W cytowanym badaniu wśród tych, którzy nie mieli styczności z kampanią wyborczą, większość - 62\% - nie poszła do urn, wobec $37 \%$ respondentów, którzy zagłosowali. Wynik ten pokazuje, że istnieje związek między posiadaniem jakichś informacji o polityce, w tym przypadku o kampanii wyborczej, a aktywnością wyborczą. Poza zasięgiem informacji o kampanii znajdowały się osoby nieinteresujące się polityką ${ }^{20}$. Autor badania konkluduje,że mimo dużego zainteresowania wyborami w porównaniu do 2015 roku sama kampania w mniejszym stopniu koncentrowała uwagę Polaków. Dla ponad 2/3 badanych była mało merytoryczna i nie uzyskali oni wiedzy o kandydatach startujących w ich okręgach ${ }^{21}$.

$\mathrm{Z}$ analizy badań społecznych wyłania się wniosek, że ukształtowane preferencje polityczne mają decydujący wpływ na decyzje wyborcze. Kampanie wyborcze nie przynoszą wielkich zmian w tym zakresie. Wygranie wyborów przez partię wiąże się z zadowoleniem wyborców z tego faktu. Tozaś pokazuje, że na percepcję wyborów wpływa ich wynik.

\section{Podsumowanie. Komponenty społecznej percepcji wyborów}

Przeprowadzone analizy badań demoskopijnych oraz własnych badań wskazują, że istnieje pewna różnica windywidualneji społecznej percep-

\footnotetext{
17 Centrum Badania Opini Społecznej, Społeczne reakcje na wynik wyborów, komunikat z badań nr 153/2019.

18 Tamże.

${ }^{19}$ Centrum Badania Opini Społecznej, Odbiór kampanii wyborczej i aktywność polityczna w Internecie przed wyborami parlamentarnymi, komunikat z badań nr 152/2019.

20 Tamże.

21 Tamże.
} 
cji wyborów. Polega ona na tym, iż w pierwszym przypadku w większym stopniu mamy do czynienia z koncentracją na indywidulanych kandydatach $\mathrm{i}$ ich cechach, na spektakularnych wydarzeniach. Jeśli chodzi o badania społeczne, które nie odnoszą się wprost do omawianego zagadnienia, można jedynie przypuszczać, że zdiagnozowane po wyborach dominujące emocje, takie jak zadowolenie, rozczarowanie, obawa, radość, zaskoczenie czy zniechęcenie, stanowią element społecznego obrazu wyborów.

Z indywidualnych wywiadów wynika, że respondenci zwracają uwagę na osoby, na przykład na tych kandydatów, którzy w jakimś stopniu są im bliscy (jak tata koleżanki). Z drugiej zaś strony obiektem uwagi jest zachowanie - jak odnotowana rozczarowująca niekonsekwencja w działaniu politycznym (przypadek Biedronia). Przedmiotem uwagi są partie polityczne czy koalicje - zarówno te, które są dobrze znane, jak i te, które pojawiły się dopiero w wyborach 2019 roku. Jednakże wskazać można, że im silniejsza pozycja partii/koalicji, tym ma ona większą zdolność do przyciągania uwagi. Zatem siła wpływu, potencjał partii odgrywa tutaj duże znaczenie.

W strukturze percepcji są więc uwidocznione: osoby/liderzy, zachowania, partie polityczne, ich potencjał. Emocje i oczekiwania mają binarny charakter. W wywiadach rozmówcy nie kryli wyrazistych emocji, czasami posługując się inwektywami, a często pospolitymi określeniami. Główne emocje, które im towarzyszyły, to: akceptacja vs negacja, rozczarowanie vs zachwyt, zadowolenie vs niezadowolenie, zaufanie vs nieufność. Z kolei respondenci w badaniu CBOS określali swój emocjonalny stosunek do wyników wyborów w kategoriach rozczarowania, radości, obawy, zaskoczenia i zadowolenia.

W oczekiwaniach można dostrzec potrzebę spokoju społecznego, ładu i porządku. Ciekawym elementem percepcji społecznej są interpretacje - bo to właśnie z nimi rozmówcy pozostają. Emocje mogą być chwilowe, podobnie jak wydarzenia. Interpretacja jest najtrwalszym elementem społecznej percepcji, ponieważ jest nie tylko zapamiętywana, ale również przekazywana.

Zatem w społecznej percepcji wyborów wyróżnić można elementy względnie trwałe (wydarzenia, zjawiska), nietrwałe (emocje) i trwałe (interpretacje). Choć oczywiście i w tym zakresie można spodziewać się zmian, na przykład pod wpływem silnej argumentacji.

Wybory w 2019 roku będą zapamiętane przede wszystkim jako kontynuacja rządów Prawai Sprawiedliwości i ich polityki społecznej, która dla jednych jest rozdawnictwem, a dla innych zaspokojeniem podstawowych potrzeb. 


\section{Bibliografia}

G.V.Caprara, Ph.G. Zimbardo, Personalizing Politics. A Congruency Model of Political Preference, «American Psychologist» 2004, vol. 59 (7).

D.T. Kenrick, S.L. Neuberg, R.B. Cialdini, Psychologia społeczna, przekł. A. Nowak i in., Gdańsk 2002.

Ż. Krawczyk-Antońska, Pobudzić a zostać pobudzonym. Emocje w polityce, Katowice 2013.

E.M. Marciniak, Personalizacja zachowań wyborczych w Polsce w kontekście Modelu Zgodności Preferencji Politycznych, Warszawa 2013.

E.M. Marciniak, Pozyskiwanie uwagi jakonarzędzie marketingu politycznego, «Studia Politologiczne» 2010, vol. 16.

M. Ratalewska, Spostrzeganie społeczne i jego znaczenie w procesie komunikacji międzyludzkiej, «Studia Ekonomiczne Regionu Łódzkiego» 2013, nr 11.

H. Schoeck, Zawiść. Źródło agresji, destrukcji i biedy, przekł. K. Nowacki, Warszawa 2012.

K. Skarżyńska, Spostrzeganie ludzi, Warszawa 1981.

K. Skarżyńska, Potoczna percepcja iewaluacja rzeczywistości społeczno-politycznej, [w:] J. Reykowski (red.), Potoczne wyobrażenia o demokracji. Psychologiczne uwarunkowania i konsekwencje, Warszawa 1995.

B. Wojciszke, Człowiek wśród ludzi. Zarys psychologii społecznej, Warszawa 2002. 